\title{
Comparison and Contrast between First and Second Language Learning
}

\author{
Javed Akhter (Corresponding author) \\ Department of English Literature and Linguistics, University of Balochistan Quetta Balochistan Pakistan \\ E-mail: sangatjavedakhtar@gmail.com \\ Muhammad Amin \\ Department of English Literature and Linguistics, University of Balochistan Quetta Balochistan Pakistan \\ Faria Saeed \\ Department of English Literature and Linguistics, University of Balochistan Quetta Balochistan Pakistan \\ Shumaila Abdullah \\ Department of English Literature and Linguistics, University of Balochistan Quetta Balochistan Pakistan \\ Khair Muhammad \\ Department of English Literature and Linguistics, University of Balochistan Quetta Balochistan Pakistan
}

Doi:10.7575/aiac.alls.v.7n.1p.130

URL: http://dx.doi.org/10.7575/aiac.alls.v.7n.1p.130
Received: 19/09/2015

Accepted: 13/11/2015

\begin{abstract}
This research paper tends to focus on comparison and contrast between first and second language learning. It investigates the different factors that have inhibiting influences on the language learning process of the learners in the two different environments. There are many factors involved in this respect. The age factor is one of the vital factors that influence the progress of learners in the language learning process. The other factor between first and second language learning, which mostly influences the performance of second language learners, is language input in terms of the quantity and quality in both cases of the limitations of the second language learning in classroom. This research study also studies the language input in both cases and limitations of second language learning in classroom. The present research also investigates the individual differences between first and second language learning, covering aptitude of the language learner, motivation of teacher and classmates, language anxiety and language ego. This research paper suggests that motivation of the teacher and other class fellows, aptitude of learner and teacher's instructions and teaching methodology as well as classroom setting may help the second language learners to overcome their language anxiety and language ego in the classroom.
\end{abstract}

Keywords: First language learning, Second language Learning, Age Factor, Individual Differences, Language Input, Language Anxiety and Language Ego

\section{Introduction}

Language learning is essentially a problem in psychology, individual, dyadic, and social phenomena. First language and second language learning are commonly considered as two different domains due to their difference of age and environment. (Oxford, R.L, 1990, p. 4). He distinguish first language and second learning, that the first arises from naturalist and unconscious language use, whereas the latter represents the conscious knowledge of language that happens through formal instruction. Fillmore suggests that this definition seems too rigid because some elements of language use are at first conscious and then become unconscious through practice (Fillmore, L. W., 1989, p. 311). On the other hand, Brown argues that both learning and acquisition are necessary for communicative competence particularly at higher skill levels. Therefore, learning acquisition continuum is more accurate than dichotomy in elaborating how language abilities are developed (Brown, H.D., 1994, p. 48).

However, the interrelation between learning and acquisition does not prevent argument around the long list of limitations of second language learning in the classroom. R. Allwright answered the question why do not learners learns what teacher teach them? He argues that the apparent failure of teaching to have a significant effect on second language learning can be ascribed to the failure to realise that planned teaching is only one part of the input available to the classroom language learners, even outside the four walls of the classroom. Therefore, formal and informal language learning are interwoven, acting as the two axes of language fluency. Native speakers' speed of articulation is affected not only by their ability of retention, but also by the amount of prefabricated chunks stored in the long-memory and retrieved when needed, a skill which promotes fluency (Allwright, R, 1978, p. 209). Given the language of the speech community and the innate physical and mental capacities of the newcomer to that community, what happens between 
the time of his ignorance of the national language and his eventual control of it, either partial or complete? The process is a type of learning that involves the establishment of a set of habits that are both neural and muscular, and that must be so well learned that they function automatically. Language learning divides language learners into two main classes, those who as infants are learning the first language and those who, having attained faculty in first language, are learning another as a second language. There are many comparisons and contrasts to be made between these two classes of language learners.

In the case of first class of language learners, there is a fascinating contest between their innate potential for use of parole and the community's highly systematized practice of langue. The latter always win and impose upon the loser almost completely. The outcome long obscured the arresting significance of what the infants bring to struggle. There is vital force in the infants that finds delight in incessant verbal play, with the result that within a matter of months, they break the code of the language being used about them, and within a few years, they have completely mastered it in spoken form. Nelson Brooks claims that, "The human infant merits full credit for his contribution to this remarkable synthesis" (Brooks, Nelson, 1964, p. 22). Second language acquisition is by means easy task. It is important to note that the process of second language acquisition is complex at all ages. The variation in the case with which different young children acquired second language, ranging from six-year-old who appeared to acquire nothing from the first seven months of her immersion in English to others with extremely rapid development. Therefore, the individual who already possesses first language brings to the learning of a second language a very different set of physical and mental capacities. Partial, if not complete, command of one linguistic code has already been attained, and it can be both a help and a hindrance in learning the second language. The contradictions for learning second language are almost identical for all learners of the first language, differ widely for the second-language learner. One of the greatest differences is whether he finds himself in the cultural field of the language in question, by being either geographically within its borders or in direct contact with it in an authentic cultural island transplanted to a distant place.

\section{Literature Review}

There are many different theories of language learning, which has been and can be applied to the process first and second language learning. In this regards, "Intercultural Competence in Young Language Learners: a case study" Thesis by Robyn A. Moloney submitted in partial fulfilment of the degree of Doctor of Education, to the University of Sydney Australia, On September 2007. It is brilliant, interesting study, thought pro study on the subject, which attempts to prove logically that young children are interculturally competent learners rather than the adults. Aladdin Assaiqeli wrote a research paper entitled "Theories of language learning: A contrasting view" in which he discussed many theories of language learning but touched the issue of comparison and contrast between the first and second language learning very slightly. In addition, the critical hypothesis $(\mathrm{CH})$ as proposed by Lenneberg (1967), opines that primary language acquisition must occur during a critical period that ends at about the age of puberty with the establishment of cerebral lateralization of function. Any language learning after the age of puberty will be slower and less successful than normal first language learning (Krashen 1975, Lenneberg 1967, Scovel 1969). Children are superior to adults in acquiring the sounds of L2 (Asher, J. \& Garcia, R, 1969; Olson \& Samuels, 1973; Seliger, Krashen, \& Ladefoged, 1975; Oyama, 1976; Snow \& Hoefnagel-Hohle, 1977). Krashen, Scarcella \& Long wrote many things on the subject of child-adult differences in the second language acquisition. (Krashen, Scarcella \& Long, 1982). The present research tends to highlight the comparison and contrast between adults and children in second language learning in the light of brilliant language learning theories of these linguists to prove that there is are many factors including age factor involved in the process of the second language learning. In addition, the present research study also suggests how to overcome the hindrances and hurdles in the second language learning to make it effective and successful.

\section{Debate and Discussion}

Age factor and other factors are involved in the process of language learning. Age difference is of great importance in second language learning. It largely determines the extent to which the second language learner retains the faculties that made it possible for him to learn his first language. Therefore, children learn languages quickly and better than adults do. According to Harley, children, learn languages better than adults do. (Haley, 1986, p. 4). Children are considered to be naturally gifted artists, who learn English as a second language within no time but when the critical period ends and the puberty period starts they begin to develop psychological and emotional interference, shyness, hesitation, anxiety and ego in their behaviour, so they become slower in their second language learning process. Brown describes that language ego can be damaging to language learning as follows:

"At, these inhibitions are heightened in the trauma of undergoing critical physical, cognitive and emotional changes. Their egos are affected not only in how they understand themselves, but also on how they reach out beyond themselves, how they relate to others socially, and how they use the communicative process to bring on affective equilibrium" (Brown, H. D., 1994, p. 70).

In addition, some linguists thought that language ego is one of the psychological interferences that hinders and causes handicap in adults to learn second language. Guiora (1972) was the first linguist, who discovered the notion of language ego, claiming that this agent occurs when the learner is aware of the limitations and boundaries of a language. Therefore, language ego refers to the very personal nature of new Language Learning and is associated with the fear of making mistakes. These mistakes work as internal and external threats to one's ego. Ego boundaries, according to M. E. Ehrman, "are the degree to which individuals tend to compartmentalize their experience, which effects receptivity to outside influences such as new languages and cultures. Learners, like others, try to build set of defences to protect the ego. In classroom, students' learning preferences depend on how thick or thin their ego boundaries are, Students with 
thin ego enjoy content-based learning where the focus is on what is being said more than how it is said. Many of them prefer non-linear approaches to learning and enjoy unexpected learning events. Students with thick ego boundaries, on the other hand, prefer a clearly structured curriculum and display some discomfort with role-playing and similar suspenses of everyday identity" (Ehrman, M. E. 1999, p. 69). The great advantage of children is their mental flexibility to learn languages, which adults are lacking. Therefore, children produce native like-accent in second language learning. This is a great hindrance in case of adults to produce native like- accent in second language learning. H. D Brown observes as follows:

"Children who acquire a second language after the age of five may have a physical advantage in the phonemic control of second language is physically possible yet that mysterious plasticity is still present. It is no wonder that children acquire authentic pronunciation while adults generally do not, since pronunciation involves the control of so many muscles" (Brown, H.D., 1994, p. 51).

However, children can sound similar to their second language class fellows very quickly with all cultural background. While the adults, on the other hand, can hardly attain the depth of cultural background. In addition, in the case of second language learning limited input, language anxiety and language ego are also main factors that influence the process of second language learning in the classroom. Adults cannot gain the depth of cultural background, which makes them able to learn second language as the native speakers of a language do. M. E. Ehrman terms this the Critical Period (CPT), (Ehrman, M.E., 1996, p. 180). According to Critical Period Hypothesis, adults do not possess the same plasticity as children, which enable them to cope with new mental activities. Therefore, the adults face many difficulties to achieve native like fluency because the developmental changes in the brain that effect the nature of language acquisition after the end of the critical period. L.S. Vygotsky (1978) explains this hypothesis in a different way, arguing that the adults tend to be more analytical in learning languages than children, who tend to be more holistic. Therefore, children acquire the langrage as it is formed and produced by others. On the other hand, the adults unlike children often think of how a construction is formed before using it in conversation.

The impact of $\mathrm{CPH}$ on first language acquisition does not receive consensus of all linguists and classroom researchers. Lightbown and Spada cite a research study carried out by Snow and Hoefnagel-Hohle on a group of English speakers learning Dutch as a second language. The study includes learners from all age categories from six to sixty year olds. The study proves that adolescents neither children nor adults are the most successful learners because they learn faster in the early stages of second language development. The young learners have some difficulty in learning tasks, which are beyond their cognitive maturity. The research shows that adults and adolescents are able to make a considerable progress in second language learning when they use the language on a daily basis in social, professional and academic interaction (Lightbown and Spada, 1999, p. 60).

Whereas, in the case of adult second language learners, who crossed the premises of critical period and reached the boundary of puberty period, second language learning process becomes comparatively slow. The critical period hypothesis $(\mathrm{CPH})$ as proposed by Lenneberg (1967) opines that primary language acquisition must occur during a critical period that ends at about the age of puberty with the establishment of cerebral lateralization of function. A strong implication of $\mathrm{CPH}$ is that the processes involving in any language acquisition, which takes place after the age of puberty, will be qualitatively different from those involved in first language acquisition. A commonly drawn, though not necessary, corollary of $\mathrm{CPH}$ is that any language learning that takes place after the age of puberty will be slower and less successful than normal first language learning (Krashen, 1975, Lenneberg, 1967, 1969 and Scovel, 1969). Adult second language learners are indeed less likely than young children to master second language are. They are doomed to failure. In this sense, it can easily be observed that their second language learning ability is affected badly. Therefore, language ego is one of the major factors that hinder the adults to learn a second language. It does not mean that language ego is only one specific factor to hamper second language learning process. In addition, many other factors hamper a person to learn second language. However, the most dominate factors in this regard, is ego, which generates powerful feelings in the mind of adult that hamper or makes the learning process slower and slower. For this reason, adults are not as successful L2 learners as children are because more they think little they speak. They are actually afraid of speaking as they think that people might make fun of them if they will not pronounce the words correctly, make grammatical mistakes. If fluency will not be there the people would crack jokes on them, what if they did not answer well That is why, ego raises such questions in the mind of an adult L 2 learner and that is how it slowdowns the learning process and proves that he is not getting fruitful results.

This research rejected all theories of age factor's impact on second language learning. The adults are advantaged over children in a number of ways. Young children can learn second language faster and gain a native like fluency. They can speak second language in very limited vocabulary, simple grammar and their sentences are generally based on concrete topics. On the contrary, the adults unlike children possess a higher level of cognitive development of mind, vast knowledge and experience of life, which enable them to achieve language proficiency, competence and fluency on satisfactory level in a very short period. However, this is not a hindrance for those who have already skipped puberty to learn second language. This rejects the influence of the critical period on the second language learning process. For this reason, the so-called critical hypothesis is wrong and does not possess solid ground. Many studies and theories on language learning prove it so.

Modern linguistics has copiously acknowledged the value of input in the context of language acquisition because it carries primary importance in acquiring L1 and L2. This process takes place in the target language while using the target language culture as its pedestal and thus, becomes more influential when it is provided according to the age of the 
learners. In the case of educated atmosphere, it can be made possible through games and certain other activities under the shelter of the target language. In fact, the credit of introducing the concept of input into the world of linguistics goes to Lev Vygotsky whose Zone of Proximal Development (ZPD), resulted a revolutionary change in conceptions related to the second language learning. Vygotsky is of the opinion that there is a gap between current knowledge of the child and potential knowledge. He calls it a zone and believes that a child learns best when given small pieces of information, which aid them through the ZPD. Krashen on the other hand, proposed input hypothesis that is I +1 . He considers that human beings acquire language through 'comprehensible input' (Johnson 2004, p. 47; Krashen 1987; Krashen \& Terrell 1983; Macaro 2003). According to Krashen human beings are blessed with natural linguistic competence which he terms ' $I$ ' while he calls the level of language, which he or she acquires next to his already acquired competence as ' 1 '.

Nevertheless, the idea of linguistic input is licensed when it receives the fever of behaviourists who define behaviour as a conditioned response to stimuli. In the opinion of Chastain (1976), the "behaviourists concluded that all learning consisted of some form of conditioning" (cited in Hadley 2001, p. 105). Pavlov, the most eminent Russian behaviourist, too, believes in language input, as acquiring language through behaviour is also an input. He exercised his conditioning process on dogs. The dogs were conditioned and they responded to the ringing bell. B.F. Skinner followed and developed further Pavlov's theory of conditioning and called it the process of learning as operant conditioning. Thus, language learning is also a part of this process of operant conditioning. In this context, in this process, he affirms that learning takes place because of the reward given for accomplishing the correct task. While punished the learner for not achieving his goal. (Van Patten 2003). He exercised his theory of operant learning on rates while using Skinner's box as a tool where rates were put to test. He applied this experiment to the language learning process. However, Noam Chomsky's ideas are quite different in this regards. He believes in innateness. Noam Chomsky proposes theory of Universal Grammar or UG and believes that children needs to be given the input of lexical items only and that grammatical knowledge, which is hardwired into ones' mind, develops all to itself. Thus, language input is an essential fact in the process of language acquisition. It contains the seeds that may give birth to a developed linguistic competence with the passage of time.

\section{Conclusion}

The present research study indicates contrasts between first and second language learning. These are complex and involved in age difference, personal difference and difference of environment. This paper also shows difference of the phonemic inventory, and language structures between first language and second languages, which have vital impact on second language learners in producing the sounds of second language in the case of second language learner as the native speakers do. The difference between structures of first and second language also influences the language proficiency, fluency and accuracy of the learner in performance, competence and learning of second language. As a result, solution of this problem is that motivation of teacher and classmates, aptitude of learners, instructions and teaching methodology of the learned and motivated teacher as well as classroom atmosphere may prove helpful for second language learners in the classroom. If these steps will be taken, they are helpful for second language learners to overcome their language anxiety and language ego.

\section{References}

Allwright, R. (1978). Concluding Comments on Second Language Acquisition in Context. In: Ellis, R. (ed.), Second Language Acquisition in Context. Cambridge: Cambridge University Press, Prentice Hall. Pp. 209-212.

Asher, J. \& Garcia, R. (1969). The Optimal Age to Learn a Foreign Language. Modern Language Journal 53, $334-342$.

Assaiqeli, Aladdin. (2013). Theories of language learning: A Contrasting View. Scholarly Journal of Scientific Research and Essay (SJSRE) Vol. 2(3), Pp. 34-43, March 2013. Available online at http:// www.scholarlyjournals.com/SJSRE ISSN 2315-6163 C 2013 Scholarly-Journals.

Atchison, J. (1974). General Linguistics. UK: English Universities Press Ltd.

Brooks, Nelson. (1964). Language and Language Learning. New York: Harcourt, Brace and World, Inc.

Brown, H. D. (1994). Principles of Language Learning Teaching. New Jersey: Prentice Hall.

Brown, H. D. (2001). Teaching by Principles: An Interactive Approach to Language Pedagogy. New York: Pearson Longman.

Brown, H.D. (2000). Principles of Language Learning And Teaching (4th edn.). New York: Addison Wesley Longman, Inc.

Brown, R.O. (1973). A First Language: The Early Stages. Cambridge, MA: Harvard University Press.

Brumfit, Christopher. (1984). Communicative Methodology in Language Teaching: the Role of Fluency and Accuracy. Cambridge: Cambridge University Press.

Chomsky, N. (1986). Knowledge of Language: Its nature, origin, and use. New York: Praeger.

Crystal, D. (2003). English as a Global Language (2nd edn.). United Kingdom: Cambridge University Press.

Ehrman, M.E. (1996). Understanding Second Language Learning Difficulties. California, USA: Sage Publications, Inc.

Fillmore, L. W. (1989). Teachability and Second Language Acquisition In: Schiefelbusch. R. L. and Rice, M. L. (eds.), The Teachability of Language. New York: Paul H. Brooks Publishing Co. Pp. 311-350. 
Firth, J.R. (1968). Selected Papers of J. R. Firth. 1952-1959. (ed. F. R. Palmer). London: Longman: Longman Linguistic Library.

Fromkin, V., Rodman, R. (1998). An Introduction to Language (6th edn.). USA: Rinehart and Winston.

Hadley, Alice Omaggio. (2001). Teaching Language in Context. Boston: Heinle \& Heinle.

Halliday, M.A.K. (1975). Learning How to Mean: Explorations in the Development of Language. London: Edward Arnold.

Halliday, M.A.K. (1978). Language as Social Semiotic: the Social Interpretation of Language and Meaning. London: Edward Arnold.

Harley, B. (1986). Age in Second Language Acquisition. England: Multilingual Matters Ltd. Johnson, Marysia. (2004). A Philosophy of Second Language Acquisition. New Haven: Yale University Press.

Harlow, England: Longman. (2010). Theories of Language: Halliday's Theory-language as a socialsemiotic.RetrievedFeb.24,2010.http://golum.riv.csu.edu.au.

Young, R.F. (2009). Discursive Practice in Language Learning and Teaching. WileyBlackwell.http://en.wikipedia.org/wiki/Leonard_Bloomfieldhttp://www.newworldencyclopedia.org/

Harris, R., and Taylor, T.J. (1989). Landmarks in Linguistic Thought: The Western Tradition from Socrates to Saussure. Great Britain: Routledge.

Johnson-laird, P.N. (1990). Mental Modals. Cambridge University Press.

Krashen, Stephen D. (1975). The Critical Period for Language Acquisition and its Possible Bases. In: D. Aaronson \& R. W. Rieber. (eds.), Development Psycholinguistics and Communication Disorders. New York: New York Academy of Sciences.

Krashen, Stephen D. (1987). Principles and Practice in Second Language Acquisition. Englewood Cliffs, NJ: PrenticeHall International.

Krashen, Stephen D., and Tracy D. Terrell. (1983). The Natural Approach: Language Acquisition in the Classroom. Pergamon Press.

Lenneberg, E. (1967). Biological Foundation of Language. New York: Wiley.

Lightbown, P.M., Spada, N. (1999). How Languages are Learned (2nd edn.). Oxford: Oxford University Press.

Littlewood, W. (2005). Foreign and Second Language Learning. Cambridge: Cambridge University Press. MOHE KSA. Successful E-Learning Management Programme. National e-Learning and Distance Learning Center.

Macaro, Ernesto. (2003). Teaching and Learning a Second Language. New York: Continuum Books.

Moloney, Robyn A. (2007). Intercultural Competence in Young Language Learners: a Case Study. Thesis submitted in partial fulfilment of the degree of Doctor of Education, at the University of Sydney, September 2007.

Olson, L. \& Samuels, S. (1973). The Relationship between Age and Accuracy of Foreign Language Pronunciation. Journal of Educational Research, 66, Pp. 263-268

Oxford, R. L. (1990). ‘Anxiety and Language Learner: New Insights’: In: Arnold, J. (ed.), After in Language Learning. Cambridge: Cambridge University Press. Pp. 58-67.

Oyama, S. (1976). A Sensitive Period for Acquisition of a Non-native Phonological System. Journal of Psycholinguistic Review, 5, Pp. 261-284.

Radford, A. (1988). Transformational Grammar. Cambridge University Press.

Saville-Troike, Muriel. (2006). Introducing Second Language Acquisition. Cambridge: Cambridge University Press.

Scovel, T. (1969). Foreign Accents, Language Acquisition and Cerebral Dominance. In: Language Learning, 1969, 19, Pp. 245-253.

Seliger, H.W., Krashen, S.D., \& Ladefoged, P. (1975). Maturation Consonants in the Acquisition of Second Language Accent. Language Sciences, 36, Pp. 20-22.

Snow, C., Hoefnagel-Hohle, M. (1977). Age Differences in the Pronunciation of Foreign Sounds. In: Language and Speech, 20, Pp. 357-365.

Steinberg, D.D., Nagata, H. and Aline, D. (2001). Psycholinguistics: Language, Mind, and World (2nd edn.).

Van Patten, Bill, and Jessica Williams. (2007). Theories in Second Language Acquisition: An Introduction. Mahwah, NJ: Lawrence Erlbaum Associates.

Vygotsky, L.S. (1978). Mind in Society: the Development of Higher Psychological Processes. Cambridge: Cambridge University Press. 